RESEARCH PAPER

\title{
Middle East: A Regional Instability Prototype Provoking Third Party Interventions
}

\section{Waseem Din 2 Prof. Dr. Iram Khalid}

1 Ph. D Scholar, Department of Political Science, University of the Punjba, Lahore, Punjab, Pakistan

2 Chairperson, Department of Political Science, University of the Punjba, Lahore, Punjab, Pakistan

\begin{tabular}{|c|c|}
\hline PAPER INFO & ABSTRACT \\
\hline $\begin{array}{l}\text { Received: } \\
\text { August 26, } 2021 \\
\text { Accepted: }\end{array}$ & \multirow{3}{*}{$\begin{array}{l}\text { Third party interventions always prolong the interstate or civil wars } \\
\text { with unending sufferings and devastations. The entire Middle East } \\
\text { region is fraught with tensions, conflicts, civil wars and rivalries. } \\
\text { From strategic interests to power grabbing, sectarian divisions, } \\
\text { flaws in the civil and social structure of the state and society, ethnic } \\
\text { insurrections, and many other shapes of instability syndromes can } \\
\text { be diagnosed in this region. In the post-Arab Spring, 2011, the } \\
\text { emerging new regional hierarchical order for power/dominance, in } \\
\text { addition to the weakening/declining dominant US power in the } \\
\text { region, changed the entire shape of already conflict-ridden region. } \\
\text { New weak or collapsing states and bifurcation of the 'status quo' and } \\
\text { 'counter-hegemonic' states along with their respective allies, made } \\
\text { this region a prototype of instability in the regional security complex } \\
\text { of the Middle East, as a direct result of these developments. The } \\
\text { perpetuation of these abnormalities would not recede this instability } \\
\text { conundrum from the region, provoking third party intervention, if } \\
\text { not contained. }\end{array}$} \\
\hline es & \\
\hline & \\
\hline
\end{tabular}

\section{Introduction}

Ever since the Arab Spring, 2011, Middle East has become a prototype of instability that ultimately invites the third party intervention resulting in perpetual conflicts, interstate or civil wars with persistent insecurity in the individual states and the whole region alike. Middle East had always not been a very stable region even before the Arab Spring, yet the post-Arab Spring uprisings brought many new elements in the hierarchical order of the region that increased complexity to the earlier drivers of instability in the region. There is not a signal factor or cause that can be focused to determine this chronic insecurity and persistent instability, resulting mostly in armed conflicts in the Middle Eastern region. A number of causes and factors must be understood to evaluate the insecurity and instability of the region. They range from ongoing conflicts, whether interstate or intrastate, to the political divisions between and within the regional states. The consequences of the US-led coalition's invasion on Iraq in 2003, complicated relations 
between the regional powers, created ideological and power rivalries, and governance failures in most of the Arab countries which could help to understand the precarious situation of this region. With the gruesome result of this Arab Spring, out of 18 countries of the region in 2016, at least 7 of them used the military force on their own territory, and 11 intervened on the territory of other countries (Smith, 2017).

This instability that provoked military and nonmilitary interventions in various states of the region was further aggravated after the 2011 Arab upspring in the Middle East. It was actually driven by the three major inter-related developments. First was the weakening or declining role of the United States as an offshore or onshore balancer in the Middle East region, in the larger global context. It catered for assumption about the threat and opportunities for the local and other actors to pursue their strategic and foreign policy objectives openly. It also deepened the tensions and increased the regional competition among them. The second was power and ideological multi-polarity between the competing regional states, Saudi Arabia and Iran, that became a source of increased instability in the region. It fanned the opposing flames of sectarianism to further their respective strategic and ideological objectives for dominance in the already very volatile region. Thirdly, this strategic competition for regional dominance between the two regional power rivals is being played out in the newly weakened or collapsing states namely Libya, Yemen and Syria that were rather strong earlier on and just collapsed after the 2011 upspring in the region (Kamrava M. , 2018). These are the major three permanent sources of tensions and instability in the Middle Eastern region, apart from many others.

Then off course other indicators that highlight the civil causes of instability like poor governance, corruption, cronyism, nepotism, authoritarianism, rise of violent extremism, ethnic and sectarian violence, repression, inadequate infrastructure, lack of opportunities, development and economic growth failures within the civil sector also resulted in the tensions and instability in the region. These are the very sources and causes of perpetual instability of the Middle East region (Cordesman, 2018). These factors provide chances to the foreign powers or third parties to intervene in other countries or regions' internal affairs with impunity. Moreover, it also give chance to regional and local actors to intervene directly or through their proxies or allies to play their nefarious games, and fulfil their ulterior motives in a particular state or the region across.

\section{Understanding the Middle East Region}




\section{Middle East and North Africa (MENA)}

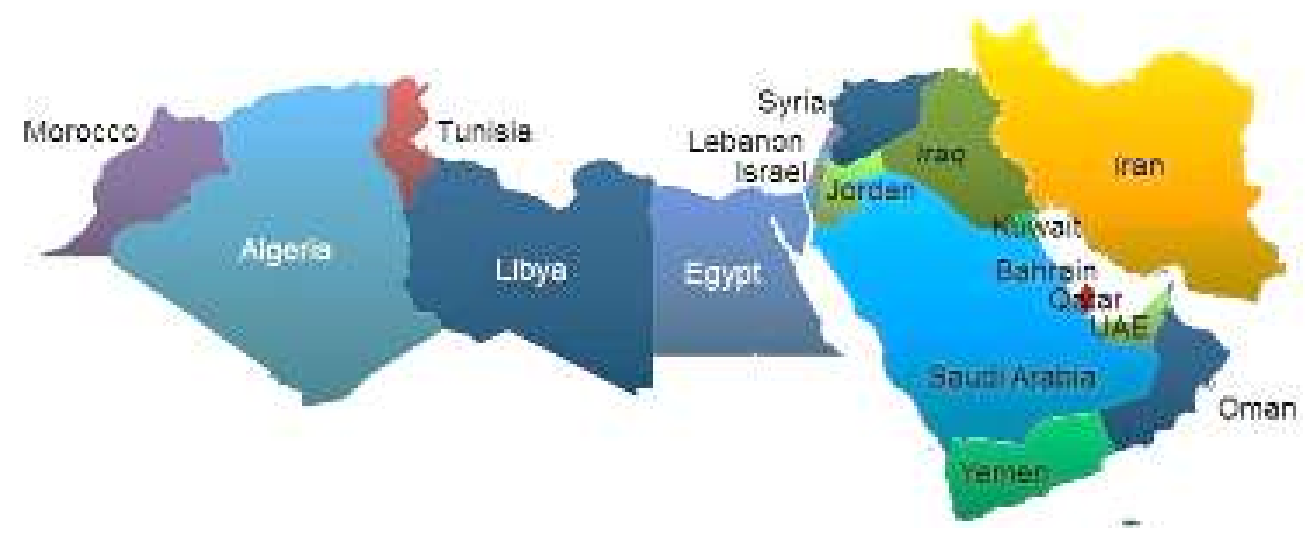

Source:https://www.google.com/search?q=Map+of+MENA+region\&tbm=isch\&imgil=zn Xk0x3W7G3aHM\%253A\%253BoqWD05Q7VHfgOM\%253Bhttp\%25253A\%25252F\#img rc=ywJoUrZGrl66SM\&imgdii=gpk22ZsF6r_E-M

Middle East is also called the MENA region as it includes seven North African states in it, mostly Muslim in population, that combine to make it the Middle East and North Africa (MENA) region, in the larger context. It is important to note that some experts and scholars also include Turkey, Sudan and Somalia in it as well, but generally 18 or 19 countries are regarded as a part of this region. Three major religions of the world i.e. Judaism, Christianity and Islam have their origin in the Middle East. After the World War I, there emerged many new states in Middle East region.

To understand the security dynamics of the Middle Eastern region, it is very important to elaborate its unique elements that distinguish it clearly from the others, and points of divergences within the region because these are the very areas that have complicated its own internal structure, all the more. On the ethnic basis in the Middle Eastern states, Arabs mostly constitute the majority population overall with exception to Iran where the Persian descent dominates demographically. Then there are Turks who constitute the majority of population in Turkey, and some minority groups like Kurds, Turkmen, Copts, Assyrians and Greek Cypriots are also present across whole region. In the smallest state of the region i.e. Israel, Jews are in majority. (Shoup, 2011). On the religious basis, Islam is the major religion of this entire region except for in Israel state. There are also some religious minorities such as Armenians, Orthodox and Maronite Christians as well (Hinnebusch, 2003, pp. 55-56). On the social and political aspect of the Middle East region, there is a rapid growth of population, unrest and anarchy in most of the states, kingdom or authoritarian regimes. All these basic elements determine the place of Middle Eastern region in the world politics. Then, due to presence of vast oil fields in the region, it has gained a strategic importance in the world with all great powers having special interests in the region, and remain engaged in through perpetual interference in the 
internal affairs of its states. (Sinkaya and Suer, 2010, p. 1). As most of these kingdom or authoritarian regimes generate a lot of wealth through their oil economy, so their rulers never need legitimacy from their society and continue with their family and authoritarian rule over people which creates instability, insecurity and unrest in the people (Sinkaya and Suer, 2010, p. 10).

\section{Regional Security Complex of the Middle East}

In the Cold War era security studies mostly focused on the realist paradigm that lacked the regional perspective and spotlighted state only as the "referent object" in their discourses and application. (Baldwin, 1997, p. 5). But, the post-Cold War scenario created a power vacuum and security challenges in the Balkan, Central Asia, Caucasia and the Middle East regions as well. This new security environment of the post-Cold War era emphasized the establishment of regional security formation. (Onis, 1995, p. 59).

Understanding the requirement of this 'new regionalism' in the security studies, Barry Buzan developed a theoretical framework in the regional perspective namely the 'Regional Security Complex Theory' in his book "People, State and Fear: An Agenda for International Security Studies in the Post-Cold War Era" (Buzan, 1991). It focused on the regional dynamics of international security. The Regional Security Complex Theory (RSCT) is based on the argument that in the power vacuum created after the Cold War era, international interaction should be regionalized and thus emphasized on the inevitability of the regional perspective of security. Buzan defines the region as a 'security complex' and says that it is "a group of states whose primary security concerns are linked together sufficiently closely that their national securities cannot realistically be considered apart from one another". He says that "within these security regions states (units) interactions are deeply rooted in durable security interdepended" within a "geographically coherent groups". (Buzan, 1998, pp. 12-15). These geographically cohering groupings are now understood as the boundaries of the regional security complex'.

To evaluate the regional insecurity and instability, coherence, conflict dynamics and complexity of intraregional relations, regional security complex theory (RCST) has separated the Middle East security complex into three sub-complexes. Countries included in each of these sub-complexes help to pinpoint the strategic rivalries, overlapping sources of destabilization, between and within the states, and more importantly highlights the epicenters of conflict zones across the region.

"Levant" Sub-Complex: This sub-complex includes Israel and its Arab neighbors, Syria, Egypt and Lebanon. The organization like Hezbollah, Hamas and PLO also operate from these countries. It mainly focuses on the Arab-Israeli conflict. Apart from the states of this sub-complex, states of Iran, Saudi Arabia, Libya, Kuwait and Tunisia who belong to other two sub-complexes of the region are also engaged in this Arab-Israel conflict. (Buzan, O. W., 2003, pp. 190-191).

“Gulf" Sub-complex: This sub-complex is consist of Iraq, Iran and Gulf Arab states (Saudi Arabia, Kuwait, Bahrain, Qatar, United Arab Emirates, and Oman). It was formed after the British withdrawal from the region in 1971. The rivalry between Shia Iran, Sunni 
Saudi Arabia and other Gulf Arab states is the main conflict dimension of this sub-complex. (Buzan, 0. W., 2003, pp. 191-192).

"Maghreb" Sub-complex: This sub-complex comprises Libya, Algeria, Tunisia, Morocco, Chad and Western Sahara States. It is the weakest among three sub-complexes of the region. It is also conflict-ridden though not directly attacked. (Buzan 0. W., 2003, p. 193).

\section{Middle East a Prototype of Instability}

Having understood the Middle East region, its various diversions, conflict dynamics and most importantly regional security complexes of the Middle East, with three sub-complexes in which various states have been engaged in small or big intrastate and interstate conflicts, it is very easy to identify the inherent instability of this region. PostArab Spring has totally changed the regional dimension of the Middle East along with a new emerging regional hierarchical order that also enhanced unrest in the already wartorn and conflict-ridden region, overall. This entire phenomena provided a chance to various regional states for using military force against either within their own state, or to intervene in other states militarily or through their proxies to fulfil the desired strategic interests, specifically in the post-Arab Spring, 2011.

Then disengagement strategy of global power, the USA, from the region has further converted it into a hotspot for power grabbing of regional and local players in search for influence and dominance, all the more. All these things have made Middle East a prototype of instability and regional disorder before other regions of the world. The global context in which role of a dominant power, ideological and power multi-polarity in the region, strategic competition between foreign great powers for influence, already weak and newly weak states along with other social, political, economic instability causes, formation of strategic alliances and enduring rivalries, which are collectively responsible for making this region a prototype of instability and insecurity, resulted in the persistent third party intervention in the internal/external affairs of this region/states at all fronts. Now all these elements of instability would be evaluated which collectively made this region so volatile, specifically in the post-Arab Spring, 2011.

\section{The Global Context of Instability}

To comprehend the global context of instability regarding the Middle East region, it would be very essential to know the prevailing international order for power distribution in the world. The current international world order is actually not related to the balances regarding the sates existing in it, rather it relies on the "preponderance of power in the hands of one nation and its allies", in the words of A.F.K Organski in his famous book "World Politics" (Organski, 1968). He visualized the international world order for power distribution in the shape of a pyramid that explains this power structure of the world in the global context. 


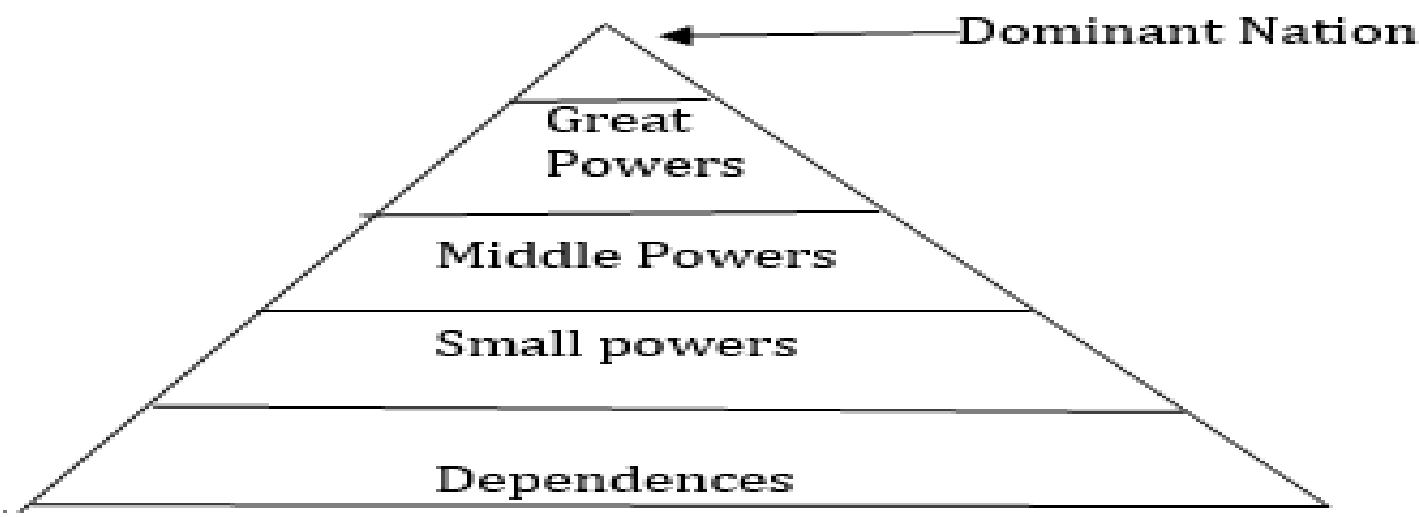

Organski's international order of power structure. (Organski, 1968, p. 365)

At the top of this pyramid is the most powerful nation which may be called as dominant power, and as we descend downwards it could be observed that number of nations increases in each layer than the numbers in the upper layer. USA is the current dominant power. Earlier it was British and in future it might be China or someone else. The dominant power controls the existing international world order, and is the recipient of the greatest share of benefits that flow from this world order. (Organski, 1968, p. 195). It is here the inherent instability grows in the structure of this international order where every state is striving to get its maximum share of benefit at all costs, whether by hook or by crook (Organski, 1968, pp. 361-365).

Keeping in mind this global world order, its power hierarchy and the nature of relations a dominant nation maintains with different levels of powers, we can evaluate the power structure of Middle East region and the resulting instability syndrome very precisely. Though Middle East has historically been remained a center of penetration for the global powers, but now the engagement strategies, priorities and polices of the global great powers have changed steadily toward this region due to changing international environment of various power blocks and regions, making it a model of persistent instability and insecurity.

The US is a dominant power and have significant political, economic, military and strategic interests in this region, and for that matter it has a heavy military presence in the whole Middle Eastern region. Notwithstanding this strong power stint by the US, there also seems a consistent decline in the influence and leverage of its dominant power towards this region now, especially in the aftermath of Arab Spring, 2011. 


\section{Where U.S. Troops Are Based in the Middle East}

Estimated number of U.S. troops

based in Middle Eastern countries

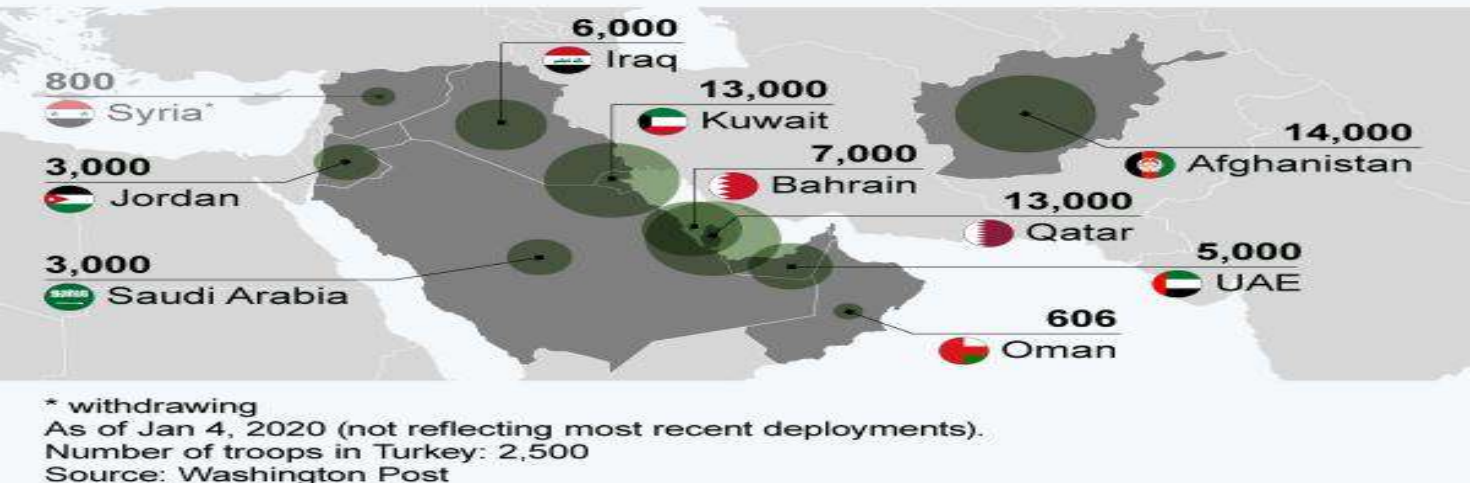

Number of troops in Turkey: 2,500

Source: Washington Post

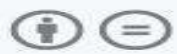

\section{Newsweele statista}

Source:https://www.statista.com/chart/9727/where-us-troops-are-based-in-themiddle-east/

The US disengagement or declining interests and influence in the Middle East region is assumed to be emerged due to several developments. These developments include, changing threat perception of the US in the Middle East, adoption of an increasing pragmatic realism by the American policymakers towards the Middle East, especially after the attack over Iraq in 2003 by the Bush administration, and the importance of 'Asia Pivot' strategy by the US in the face of rising Chinese power and influence in the Asia Pacific region. (Kamrava M. , 2018). The US has to meet all these developments and after successfully dealing with the first two challenges, its core focus is on the 'Asia Pivot' strategy which is more vital strategic interest for her now.

So, this absence of foreign dominant and great powers allowed the regional/local state actors to make their mark of influence by creating a new hierarchal order in the region, and forging new alliances to protect their position and power clout by creating further instability in the region. This is the global context of instability in Middle East region.

\section{Regional Hierarchy a Source of Instability in the Middle East}

Regional order of Middle East has shown a great inclination of unrest, conflicts and instability on the whole. The Arab Sprig, 2011 proved a catalyst for this already tensions and crisis-ridden region that further divided and polarized the countries of this region against their rivals in this new regional setup, creating further instability. The competing regional powers used all options available to them to grab this opportunity for enhancing their influence and power clout, specifically by looking at the weakening dominant international power, USA, in the region. As the absence of weakening dominant and foreign 
great powers from the region had already crated a power vacuum which heightened insecurity and instability in the Middle East, the new competition for power and dominance among the regional great powers proved a poisonous arrow in the already infected body of the Middle East.

The new hierarchical order emerging in the Middle East in the post-Arab uprisings has many competing regional powers on the upper level followed by the middle powers, who were in alliance with one of those great regional powers, and finally the weak states at the lower level in this order. This hierarchical order also became a source of instability because it had 'multiple and often overlapping' relationships with the states on all three levels of this order. The dynamics, structure and capabilities of these states capabilities of these states competing for influence and power clout diversify them from one another, and justify their position in the regional order. (Kamrava D. M., Spring, 2018). There are four major regional powers that emerged as claimant to the power and dominance in the region, after the Arab Spring, 2011 in the Middle East. They include Saudi Arabia, Israel, Iran and Turkey. They are at the top of regional hierarchy and each one among the four fits to the criteria of being regarded as a great regional power. The criteria to be regarded as a great regional power includes a claim to regional leadership, possession of necessary resources of power, strong economy, international stature, successful independent foreign policy, and have acceptance of leadership role by many states (Öniş, 2014, p. 204).

\section{Four Major Regional Powers}

The four major powers vying for dominance and influence in the region has been divided into two camps which represent the nature and structure of this hierarchy. The Saudi Arabia and Israel represent themselves as the guardian of present international and regional order led by the USA, and are called as the 'status quo' powers. Whereas, Iran and Turkey have revisionist strategy and want to break the western imposed order, and so conceive themselves as the 'counter-hegemonic' states.

Four Regional Powers

Saudi Arabia, Israel, Iran, Turkey

Status quo state

Saudi Arabia, Israel
Counter-hegemonic States

Iran, Turkey 


\section{Status Quo States}

Israel and Saudi Arabia are called status quo states as they want to maintain the status quo order of the region in which they accrue more benefits and enjoy more privileged status, in alliance with the USA and the Western block. Being status quo states, Israel and Saudi Arabia also Omnibalance with their global patrons to contain trans-state and regional threats faced to them (Hinnebusch, 2014, p. 34)

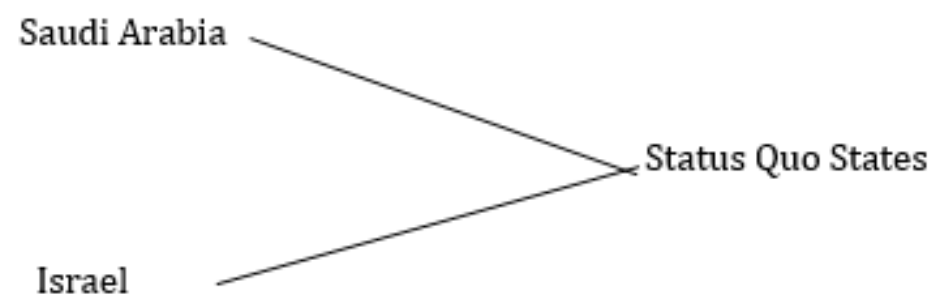

\section{Saudi Arabia}

Although very strong economically, yet Saudi Arabia lacks the enough military strength to dominate the whole states of the region. So, the pragmatic strategy is to contain the rise of other hegemons in the region. Within the Arabian Peninsula it has successfully done so through the small Gulf Cooperation Council (GCC) states as in the case of Bahrain, and trying hard to do so in Yemen, through still unsuccessful. It also uses its position as the leader of the Muslim world to fulfil its foreign policy objectives that include protection of the kingdom from foreign invasion/domination, and safeguarding the Al-Saud dynasty. (Gause, 2014, p. 189). Saudi Arabia sees Iran as an expansionist rival state with its wide influence in Syria, Iraq, Yemen, Lebanon and other countries of region through direct or its proxies in the region.

\section{Israel}

In the Middle East region Israel's safely and security is being guaranteed due to its close association with the United States, and its being the only nuclear power of region, though undeclared. Israel adopts a highly assertive posture in the region due to its militaristic foreign policy, its technological superiority, economic prosperity, soft power, and its sophisticated pre-emptive military strike capability. Israeli leaders consider themselves as a part of "moderate axis" which includes the states of Saudi Arabia, Jordan, Egypt, UAE and Bahrain and is committed to the status quo order in the Middle East region (Voller, 2015, pp. 508,510) Iran and its proxies like Shia Hezbollah are a great threat to Israel's existence, and Israel counter it through its highly militaristic foreign policy, nuclear threat perception and the technological superiority in the region.

\section{Counter-Hegemonic States}

Iran and Turkey are regarded as the counter-hegemonic powers in this new regional hierarchy of the Middle East. They are called so became they want to undermine the West-engineered global order, exactly opposite to the status quo states, in the region. 
Having revisionist ideology, they want to reverse the Omnibalance and to destroy the status quo regional order so that a new regional alliance can be forged against the USA and the Western powers (Hinnebusch, 2014, pp. 34-35). That is why they perceive themselves as the counter-hegemonic states who have challenged the west-engineered global and regional order.

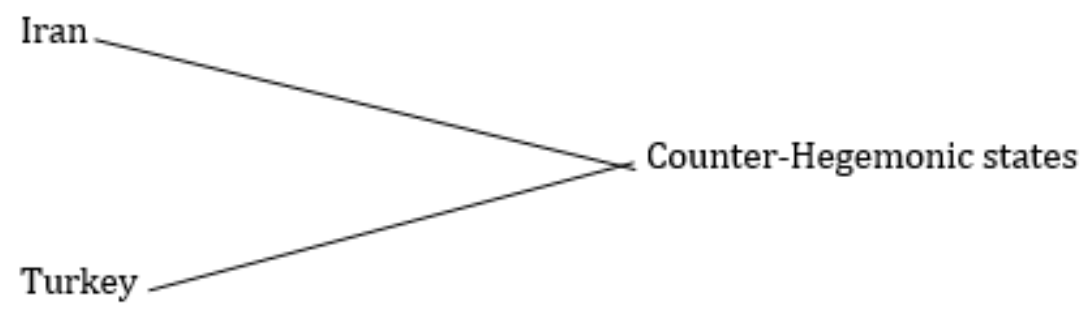

Iran

Iran considers itself as a counter-hegemonic state. Ever since the revolutionary experience from where its animosity with the USA started, it demanded for the expulsion of the US troops from the Persian Gulf, and adopted this strategy as its foreign policy objective so that it could enhance its rightful authority over the region. In the eyes of Iranian neighbors to its South, America should have a check on the Islamic republic's hegemonic ambition towards them, whereas for Iran it is the internal matter of the Middle Eastern region and should have a regional solution (Zarif, 2017). Iran has successfully challenged the international order since the post-Cold War era, but has paid a very heavy price (on economic, political, diplomatic, defense and social front) in the shape of severe and ceaseless sanctions, and international isolation imposed by the US, through maneuvering the international and regional institutions, against it. (Bahgat, 2017, pp. 167188).

\section{Turkey}

Turkey could be regarded as a 'cusp state' that lies on the political and normative edge of an established region. (Robins, 2014, p. 328). In around 2000s, Turkey stopped seeking its identity related to the European, and started perceiving itself as a central country with new identity of reviving its neo-Ottoman image, in which it was failed earlier on. . But after the Arab uprising in 2011, Turkey entered in competition with the USA, Russia, Iran and Saudi Arabia to shape in the Middle East region as a leader and not a partner. Initially, it was successful and was welcomed by Saudi Arabia and GCC states as a potent rival against Shia Iran, but Turkey's vociferous denouncement of the 2013 coup in Egypt displeased the Saudi and Emirati kingdoms and they separated Turkey from the regional diplomacy, apart from cancelling investments in Turkey as a punishment (Ibish, Cook and, pp. 5-8). Although Turkey and Iran are not genuine allies, yet Turkey's priorities are closer to Iran rather than Israel and Saudi Arabia, as both are top contenders in the regional hierarchy in Middle East. So, Turkey is a counter-hegemony state against the Western-engineered global and regional order alongside Iran. 
The competition among these four regional power, divided into two blocks, for seeking power dominance and influence in the new regional hierarchy has wreaked havoc in the already polarized region of Middle East, and is the second cause of regional tension and instability in the Middle East.

\section{Middle Powers of the Regional Hierarchy}

Middle powers of the new regional hierarchy comprise a number of regional states that have varying levels of size, power, resources and ambitions. The thing that bring them closer to each other is not the degree that makes them "system influencing" or "system affecting" states, according to Robert Koehane's definition of secondary or middle power, respectively. It is actually they are regarded as middle powers either by virtue of size or resources (Bahrain, Jordon, Tunisia), or due to their own decision of taking a lower profile in the region (Algeria, Egypt) despite they have enough size and resources to be a regional power status (Keohane, 1969, pp. 295-296). These middle powers at the middle tier of regional hierarchy are divided into two camps i.e. allied middle powers and the pragmatic middle powers.

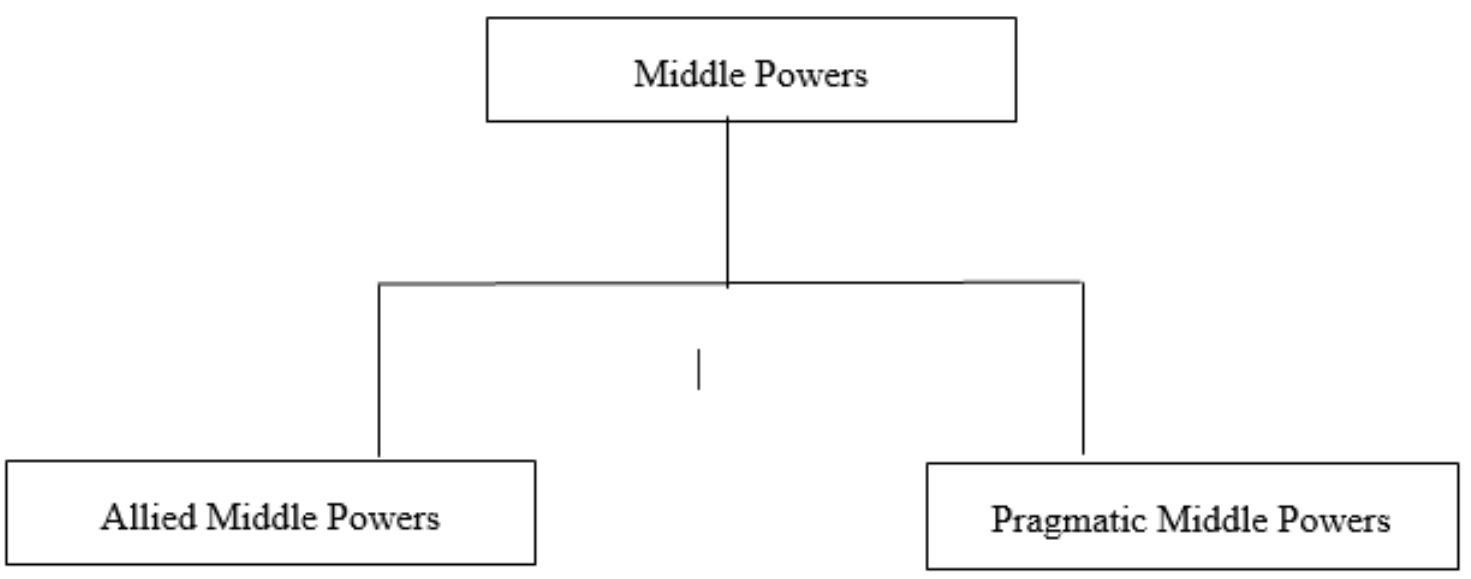

\section{Allied Middle Powers}

These states include themselves as a part of 'moderate Arab' camp and share their image with the western anchored global, and regional order in the stability of the Middle East region. This shared identity of these middle powers establishes their alliance and strategic considerations with the status quo regional power, Saudi Arabia and Israel, in the lead of the USA and the Western powers. These allied middle powers include the UAE, Bahrain, Jordan and Egypt states in the Middle East region (Keohane, 1969).

\section{Pragmatic Middle Powers}

These are the states that are more 'pragmatic' in their foreign policy pursuits, and forge alliances with the states who are more focused on the pragmatic and strategic consideration rather than on the ideological and identity factors. That is why these states 
have alliance with the counter-hegemonic regional power i.e. Iran and Turkey (Keohane, 1969). The pragmatic middle powers include Algeria, Morocco, Tunisia, Qatar and Oman states in the Middle East region.

The alliances made by these states, that form the Middle East regional order, are based on three primary interrelated reason, after the Arab Spring, 2011. These reasons include regime security (Egypt's post-quo regime's dependent relations for regime security with Saudi Arabia \& UAE), balancing against the threat (Syrian regime's alliance with Iran), and the identity factor (Saudi and Emeriti identity as moderates with Israel), over all (Keohane, 1969, p. 300), (Gause, 2015, p. 16).

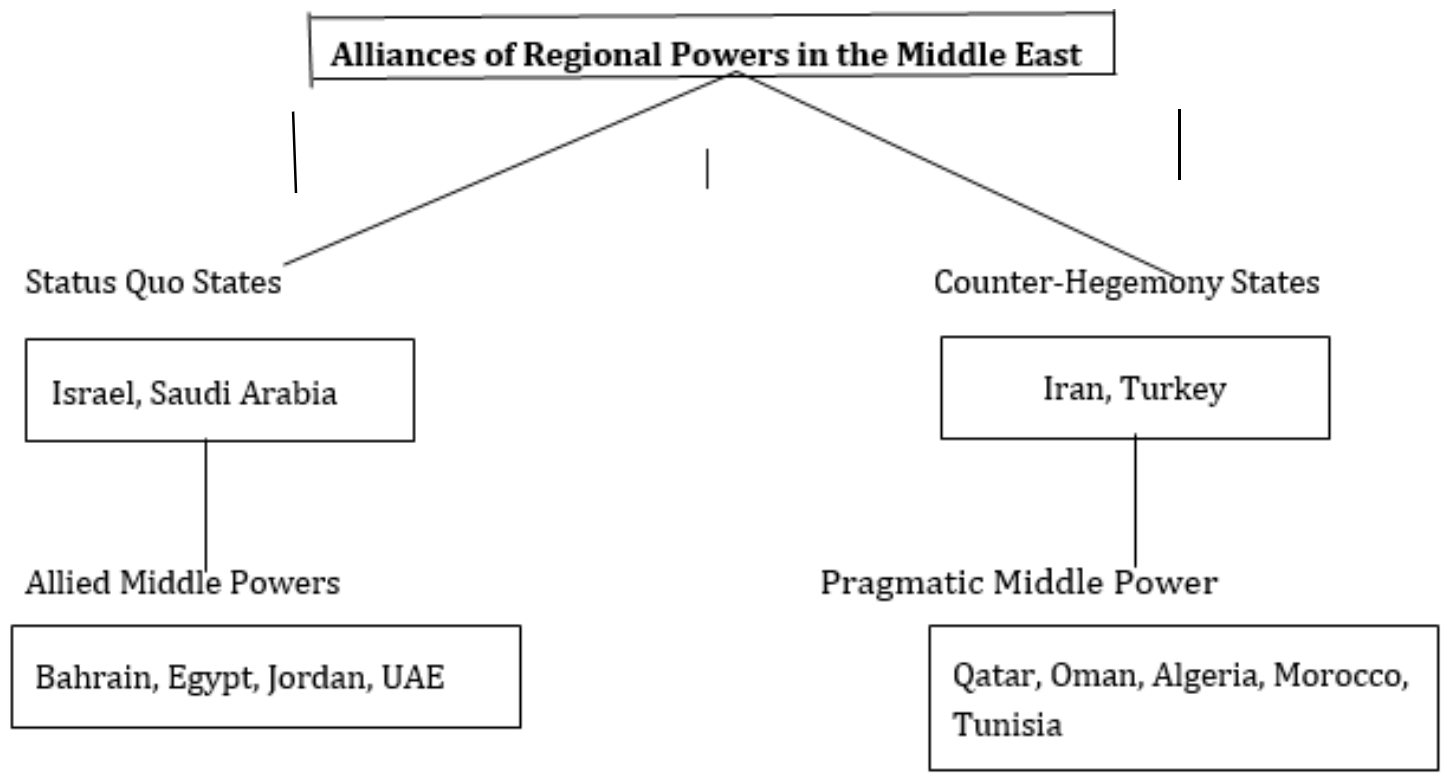

\section{Weak or Collapsing States}

These states are at the bottom level of the regional hierarchy and are called as the weak or collapsing states. These states are on the receiving end of power and get influenced by the regional powers and their allies as well. In the Middle East region Iraq, Syria, Yemen, Libya and Lebanon are the weak states. These states are influenced by the regional powers due to their weak central authority in the state. Due to collapse of state institutions and their services, people have to rely on the sub-state, non-state, regional or proxy actors for their requirements, and so make the state's structure from weak to the collapsing (Malmvig, 2015, p. 35). In the post-Arab Spring, Iran, Saudi Arabia, Qatar and UAE are the states whose support for the local proxies has created many new weak states in the region, in quest for seeking regional power and influence. Syria is the latest example of this situation that has gone weak from the powerful strong position only when Bashar Al-Asad's grip on the central government gone weak. Egypt is another example that dropped from a strong regional position to weak state after the Arab Spring due to weak central authority in the country. 
So, the whole regional hierarchical order itself is a source of instability in the Middle East region with a tug of war for power/dominance between the status quo and counter-hegemonic states, along with resistance strategies of pragmatic powers towards the status quo states and their allied powers. If we adopt A.F.K Organski's model of 'pyramid of power' in the post -2011 Middle East region with the same hierarchy of regional power setting, it would explain the complex scenario of the currant Middle East situation that has been creating tension and instability across the region with no endings in the near future.

\section{Hierarchy in the Middle East Regional System}

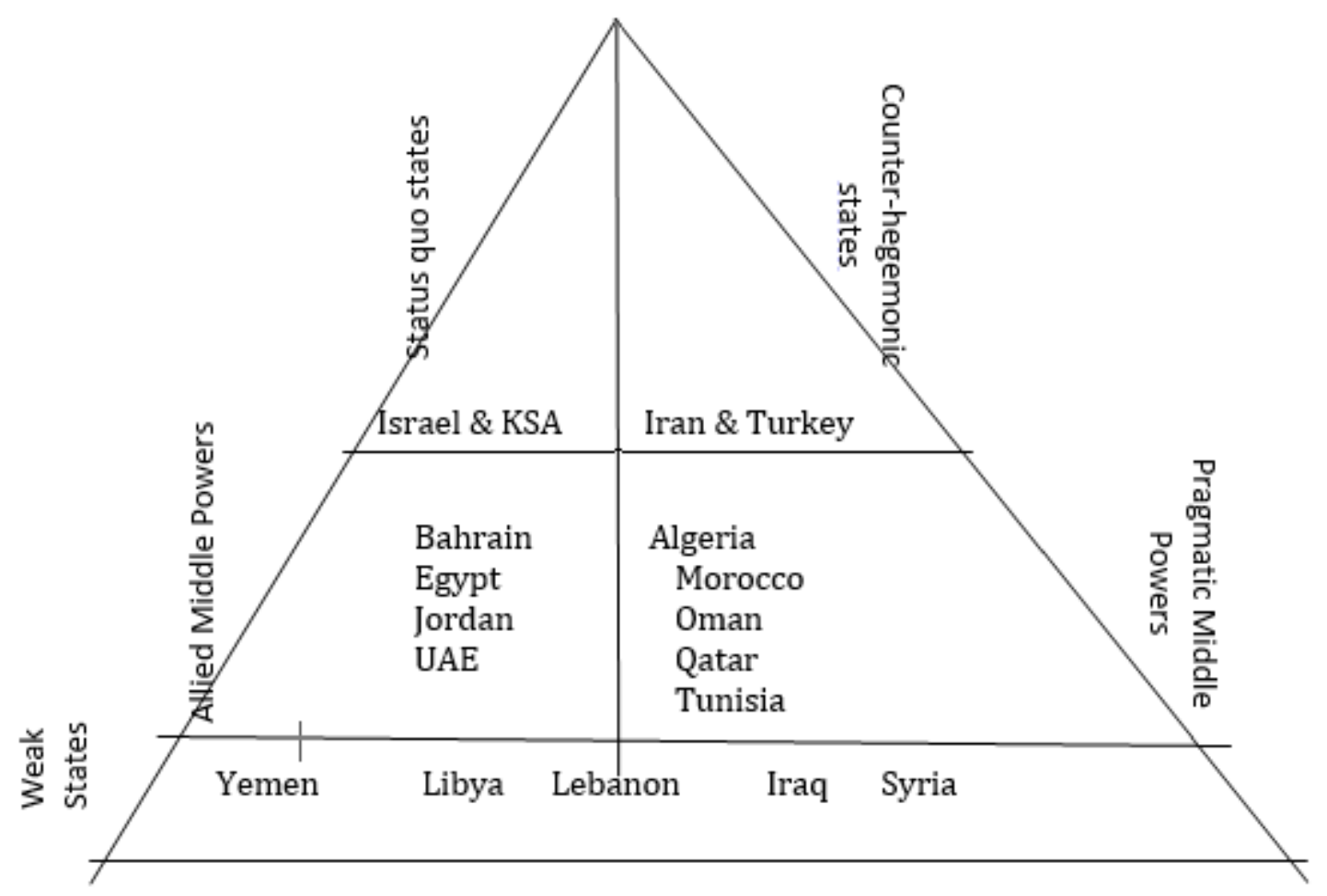

Source: (Kamrava D. M., Spring, 2018, p. 12)

\section{Instability a Rootage of the Third Party Intervention}

Instability conundrum is a real rootage of the conflicts, interstate and civil wars, unbridled authoritarian and repressive regimes, civil and social ills in the state and society, depleting space of viable political alternatives, and last but not least a consistent excuse to the third party intervention in the internal affair of a state. Middle East has been fraught with all these ills for many decades earlier than the Arab uprisings but in the post-Arab Spring, 2011 there emerged a new competition and hierarchical order in the region, along with a new set of weak states that totally destabilized the entire region. Under such precocious situation, especially when there was an absence or weakening role of a goal power in the region, some regional/local powers increased their interventional strategies 
in the other states of the region to seek power and influence for them over other. These intervention strategies created further destabilization in the states and structure of the society. But, unless instability factors are reversed with progressive social, political and economic indicators in the overall outcomes of a state, this intervention by opportunists cannot be stopped or mitigated in any way.

To understand why this third party intervention, a direct corollary of the instability, take its root, it is pertinent that we should know about the nature of the crisis or conflict of that particular affected state. If we closely look at the Middle Eastern region, we observe that mostly civil wars in various countries of the region allowed outside state or non-state actors to intervene in the internal affairs of that state. Interstate wars are rare as compare to the intrastate/civil wars in the region overall. These conflicts or wars are mostly influenced by the actors who are not originally a party to the conflict. This intervention by these third parties is done through influencing that state, either in the shape of mediation or through military and economic aid, apart from direct military intervention (Teo, Nov. 2006, pp. 828-837).

In both types of wars, whether interstate or civil wars, military interventions makes them longer and more severe, alter their likely outcomes, and directly affect the belligerent party's adopted strategies to prosecute the war (Kristian Skrede Gleditsch and Kyle Beardsley, June, 2004). But the more important question is who intervenes in these war, and which states are more prone to be intervened. In the case of interstate wars, it is almost always the other states, whereas in intrastate/civil wars, the intervention is mostly done through the non-state actors who are often proxies to the outside state (Salehyan, June,2010, pp. pp. 493-515 ).

Having understood the stature, dynamics and requisites of the third party intervention in a state due to its persistent instable environment, it can easily be stated that as long as the factors that are responsible for this instability conundrum in a state or a region are not reversed, any kind of third party intervention cannot be contained or even stopped, what to talk about its end. In Middle East states various diversions, consequences of post-Arab Spring movements, style of governments, and natural resources of the region have made it a war-torn, conflict-ridden and volatile region in the world. Most of the countries have internal rifts or civil wars creating persisted instability in this region. Starting off with four regional powers i.e. Israel, Saudi Arabia, Iran and Turkey to the regional allies of these states, all have long conflicts and rivalries with one another. For instance, Saudi Arabia and its GCC allies are long involved with Iran in a Shia-Sunni conflict, Iran is engaged with the US on the international level, and with Sunni Gulf states and Israel on the regional level for decades. In the same way Israel is confronting with its Arab neighbors on the Arabian Peninsula, on the religious lines, and with Iran it is engaged in a permanent mess for the existence, since its inception. Turkey seems a bit stable politically but the issue of Kurdish autonomy on its soil has kept it engaged militarily for decades. And after the start of Syrian wars on its borders, it intervened military in Syria and attacked the empowering Kurds on the southern border of Turkey for influence and power, in the aftermath of Syrian conflict. Apart for these four regional powers, we can observe the conflicts, tensions and instability in Iraq, Syria, Yemen, Libya, Qatar, Lebanon, Bahrain, Tunisia and even in Sudan. 
Wrapping up discussion finally, the entire gist of this research study explicates that the whole Middle East region is currently under the wave of instability due to these developments i.e. weakening of dominant power, competition among regional powers for influence and power clout, emerging regional hierarchical orders after the Arab Spring, 2011, and the creation of new weak or collapsing states in the region, apart from the civil causes of instability and social structure of the state and society, on the whole. So, it is the instability within and between the regional states that has been provoking third party interventions, whether through direct military intervention or through indirect ways of intervention, that has debilitated the entire Middle Eastern region. 


\section{References}

Baldwin, D. A. (1997). The Concept of Security. Review of International Studies. Volume 23 , Issue 1 , January 1997 , pp. 5 - 26

Barry Buzan, Ole Waever. (2003). Regions and Powers: the Structure of International Security. Cambridge University Press, UK.

Barry Buzan, Ole Waever, and Jaap de Wilde. (1998). Security: A New Framework of Analysis. Bouler, Colorado: Lynne Rienner Publisher.

Buzan, B. (1991). People, State and Fear: An Agenda for International Security Studies in the Post-Cold War Era. Hertfordshire: Harvester Wheatsheaf .

China Global Investment Tracker. (n.d.). The American Enterprise Institute And The Heritage Foundation: https://www.aei.org/china-global-investment-tracker/

Cordesman, A. H. (2018). Stability In the MENA Region: The Range of Forces Shaping Stability. Centre For Strategic \& International Studies (Csis), 102.

European Commission, Directorate General for Trade. (n.d.). Retrieved from : http://trade.ec.europa.eu

Gause, F. G. (2014). The Foreign Policy of Saudi Arabia. Boulder: Lynne Rienner.

Gause, F. G. (2015, September 17). Ideologies, alliances and underbalancing in the new Middle East Cold War. International Relations Theory in a Changing Middle East, POMEPS Studies 16.

Gawdat Bahgat, Anoushiravan Ehteshami, and Neil Quilliam. (2017). Security and Bilateral Relations Between Iran and its Arab Neighbors. New Yprk: Macmillan.

Gerges, F. (2013). The Obama Approach to the Middle East: the End of America's Moment? International Affairs. Volume 89, Issue 2, 299-323

Goldberg, J. (March 10, 2016). The Obama Doctrine: The U.S. president talks through his hardest decisions about America's role in the world. Washington, D.C: The Atlantic.

Hinnebusch, R. (2003). The International Politics of Middle East. Manchester University Press.

Ibish, Cook and. (n.d.). Turkey and the GCC: Cooperation Amid Diverging Interests.

Israel and UAE strike historic deal to normalise relations . (2020, August 13). BBC News: https://www.bbc.com/news/world-middle-east-53770859

James Sladden, Becca Wasser, Ben Connable and Sarah Grand-Clement. (2017). Russian Strategy in the Middle East. RAND Corporation. 
Kamrava, D. M. (Spring, 2018). Hierarchy and Instability in the Middle East Regional Order. International Studies Journal (ISJ )/Vol.14/ No. 4, 1-35.

Kamrava, M. (2018). Accessing the Multipolarity snd Instability in the Middle East. FPRI.

Kelly, R. E. (2007). Security Theory in the 'New Regionalism'. International Studies Review, 197-229.

Keohane, R. O. (1969). “Lilliputians' Dilemma: Small States in International Politics. International Organization , pp. 295-296.

Kristian Skrede Gleditsch and Kyle Beardsley. (June, 2004). Nosy Neighbors: Third-Party Actors in Central American Conflicts. The Journal of Conflict Resolution, 379-402 (24 pages).

Llewllyn Hughes and Austin Long. (Winter 2014/2015). Is There an Oil Weapon? Security Implications of Change in the Structure of the International Oil Market. International Security. 39 (3): 152-189

Malmvig, H. (2015, September 17). Coming in from the Cold: How we may take sectarian Identity politicsseriously in the Middle East without playing to the tunes of regional power elites . International Relations Theory in a Changing Middle East, POMEPS Studies 16.

Mead, W. R. (2014). The Return of Geopolitics: The Revenge of the Revisionist States. Foreign Affairs.

Michael G. Findley and Tze Kwang Teo. (Nov. 2006). Rethinking Third-Party Interventions into Civil Wars: An Actor-Centric Approach. The Journal of Politics, 828-837 (10 Pages).

Onis, Z. (1995). Turkey in the Post-Cold War Era: In search of Identity. Middle East Journal, 48-68.

Öniş, Z. (2014). Turkey and the Arab Revolutions: Boundaries of Regional Power Influence in a Troubled Middle East. Mediterranean Politics.

Organski, A. (1968). World Politics. Newyork: The University of Michigan, Newyork, USA.

Özgür Pala and Bülent Aras. (2015). Practical Geopolitical Reasoning in the Turkish and Qatari Foreign Policy in the Arab Spring. Journal of Balkan and Near Eastern Studies, 117.

Raymaond Hinnebusch and Anousshiravan Ehteshami. (2014). The Foreign Policies of Middle East States. Boulder: Lynne Reinner.

Robins, P. (2014). The Foreign Policy of Turkey. (Boulder : Lynne Rienner, 2014). 
Salehyan, I. (June,2010). The Delegation of War to Rebel Organizations. The Journal of Conflict Resolution, 493-515 (23 pages).

Salem, P. (2008). The Middle East: Evolution of a Broken Regional Order. Carnegie Papers.

Shirkey, Z. C. (2017). Military Intervention in Interstate and Civil Wars: A Unified Interpretation. CUNY Academics Works, City University of New York, 1-29.

Shoup, J. A. (2011). Ethnic Groups of Africa and the Middle East: An Encychlopedia. Santa Barbara, California: ABC. CLIO.

Smith, D. (2017). The Middle East and North Africa: 2016 in perspective. SIPIRY Yearlybook, pp. 75-88.

Smith, D. (2017). The Middle East and North Africa: 2016 in perspective. SIPRI Year Book.

Voller, Y. (2015). From Periphery to the Moderates: Israeli Identity and Foreign Policy in the Middle East. Political Science Quarterly.

Zarif, J. (2017, October 9). Iranian Foreign Minister: 'Arab Affairs Are Iran's Business. https://www.theatlantic.com/international/archive/2017/10/iran-persian-gulfjсpoa/542421/ 